Open Access

\title{
Thematic analysis of the international journal of educational Technology in Higher Education (ETHE) between 2004 and 2017
}

\author{
Victoria I. Marín ${ }^{1}$, Josep M. Duart ${ }^{2^{*}}$ D, Alvaro H. Galvis ${ }^{3}$ and Olaf Zawacki-Richter ${ }^{1}$
}

\footnotetext{
* Correspondence: jduart@uoc.edu ¿Universitat Oberta de Catalunya, Barcelona, Spain

Full list of author information is available at the end of the article
}

Keywords: RUSC journal, ETHE journal, Educational technology, Higher education (HE), Content analysis, Research trends

\section{Introduction}

It gives us great pleasure to be able to use this editorial to present a thematic analysis of the articles published in the International Journal of Educational Technology in Higher Education (ETHE) since it began back in 2004. The study uses the articles published in the 14 years of the journal's history (2004-2017) to show what research was carried out in the field of educational technology in higher education in this period. This qualitative analysis could be considered to be complementary to the bibliometric analysis between 2004 and 2013 (Ramiro, Ramiro-Sánchez, \& Alba-Ruiz, 2014). Although we cannot say that the study reflects all the areas of research covered during this period given that, as with any other journal of its kind, the articles published have to have passed a peer-review process and fit with the topic of the special issues proposed by the editors, but the results do show that the areas of research and the subjects covered in the articles published correspond to the research carried out in the field as a whole over the same period (Hsu, Hung, \& Ching, 2013).

As in previous studies with other journals in the field - Edutec-e (Marín, Zawacki-Richter, Pérez Garcias, \& Salinas, 2017), IRRODL (Zawacki-Richter, Alturki, \& Aldraiweesh, 2017) or Distance Education (Zawacki-Richter \& Naidu, 2016) -, the key themes covered in the publications over this period and the semantic relationships among these themes were explored with the text mining tool Leximancer ${ }^{\mathrm{Tm}}$.

\section{Methods and sample}

The method used is content analysis, which enables us to find out about this specific phenomenon besides of what can be observed or sensed (Krippendorff, 2013). Computer-based content analysis makes possible to reduce large volumes of data and being systematic -a certain sequence of steps are followed- but at the same time flexible -regarding to the coding frame (Schreier, 2014). In addition, the subjectivity involved in manual methods of content analysis is moderated when using a text mining

(c) The Author(s). 2018 Open Access This article is distributed under the terms of the Creative Commons Attribution 4.0 International License (http://creativecommons.org/licenses/by/4.0/), which permits unrestricted use, distribution, and reproduction in any medium, provided you give appropriate credit to the original author(s) and the source, provide a link to the Creative Commons license, and indicate if changes were made. 
tool as Leximancer (2016), even though the tool has to be used always in combination with the knowledge of the subject matter to be able to make sense of the concept maps that emerge from the process (Zawacki-Richter \& Naidu, 2016).

For the qualitative analysis of the emerging themes, the abstract and titles of the articles of the journal were analysed using the text-mining tool. The result of this analysis is a set of concept maps, where the concept frequency, the hierarchical order of appearance and the proximity among concepts are visualised. Each thematic region is formed based on the connectedness of concepts and is highlighted by the most relevant concept in terms of frequency and connections (relational analysis).

For this study, all articles published in RUSC/ETHE between 2004 and 2017 were reviewed $(n=355)$. Book reviews and editorial notes were excluded from the sample.

The articles were analysed according to three subsets of data: 2004-2009 $(n=134)$, 2010-2015 $(n=157)$ and 2016-2017 $(n=64)$. 2004 coincides with the year that the journal started to publish articles, mainly in Spanish, and 2015 was the last year in which the articles were published under the RUSC journal before changing its title to ETHE. Between 2010 and 2015 the papers were published bilingually, both in English and in Spanish. The last subset had to be analysed separately since all the articles in those years were only published in English. The previous subsets were analysed using the Spanish versions of the articles.

\section{Results and discussion}

The thematic analysis was conducted according to the three subsets of data. The maps are described and discussed below, by including examples of the data (Additional file 1).

Reflections and studies on the use of ICT in education at the university (2004-2009): the impact of digital practices (Fig. 1). The major focus of RUSC is placed on higher education with universities (universidades) (387 hits) as thematic region of its own. The themes universities and education (educación) (266 hits) are connected via the thematic region of technologies (tecnologías) (385 hits). Thus, the articles deal with technology-mediated university education. These three themes universities, education and technologies - stand out because they form part of the main focus and general scope of the journal. The fourth emergent theme in this period is students (estudiantes) (181 hits), as subjects of the studies conducted in the field.

Within the theme technologies, two trends regarding their use (uso) can be identified. One is the use of Information (información) and Communication (comunicación) Technologies (ICT) (TIC) tools (herramientas) for the teacher professional development (formación). Most of the authors focus on the university teachers' training, although some literature refers to initial teacher training. The other is the use of ICT tools for learning (aprendizaje). Authors are concerned with the "virtualization" of education and evaluate and reflect on digital practices in education. Some of questions addressed related to this use are: the design of Open Educational Resources (OER), the support of online learning processes or the design of different pedagogical methods with ICT (e.g., problem-based or projectbased learning). Many authors focus also on the impact of ICT on the society and 


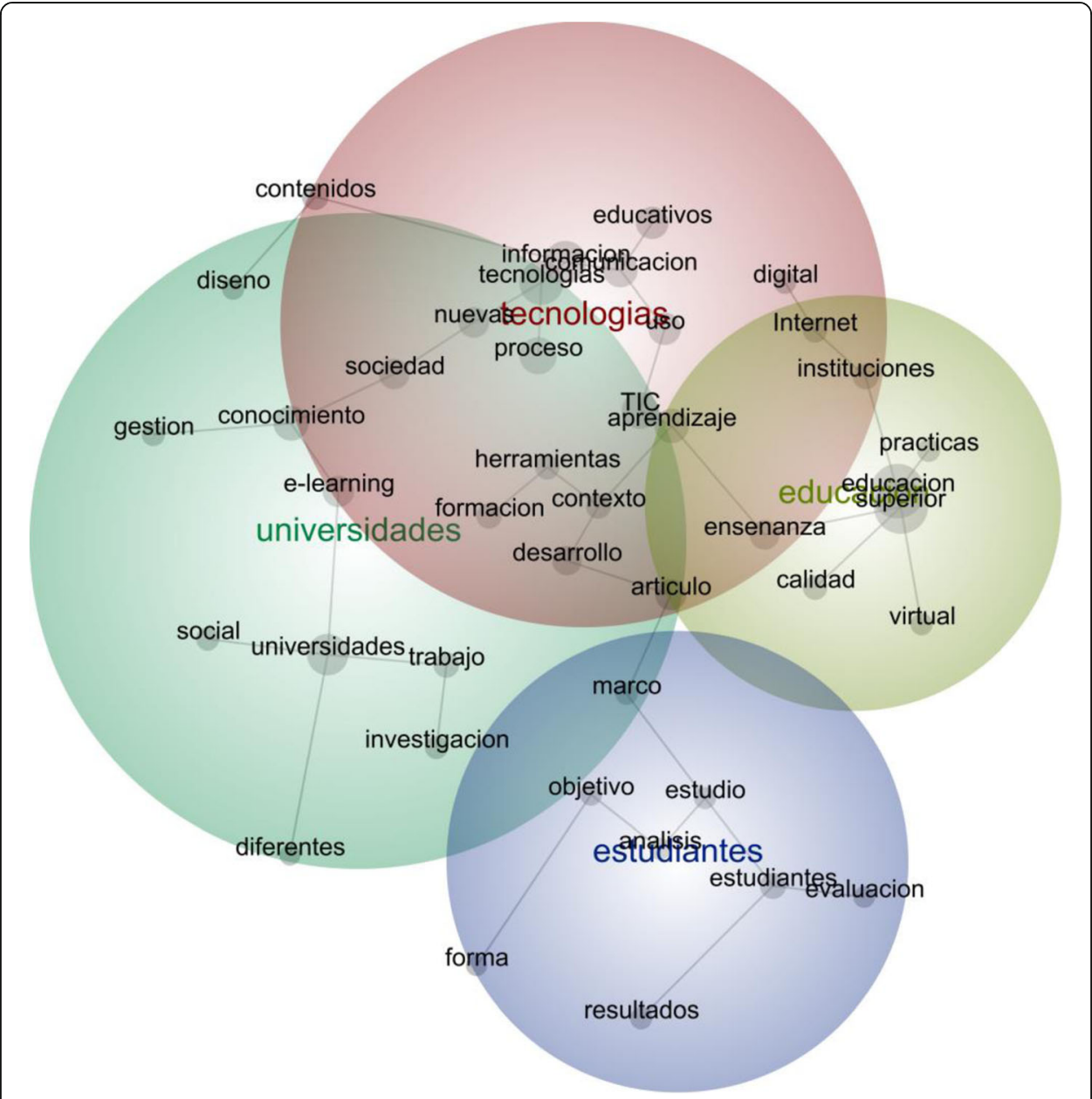

Fig. 1 Themes in the RUSC journal between 2004 and 2009 (Spanish articles) $(n=134)$

on education, in form of reflections more than empirical practice (e.g., on the digital divide) (see concept path in the theme university: gestión-conocimiento sociedad - nuevas tecnologías de la información y la comunicación - educativos).

Concerning the theme universities, a topic that can be easily recognised is related to the university as social entity (social) and connected to the society's (sociedad) function of knowledge management (gestión del conocimiento), which includes the knowledge construction and transfer. One way is through e-Learning systems (e-learning) to support communication and the exchange of information. In addition, the design (diseño) of contents (contenidos) at the university level as a process (proceso) connected to technologies is also highlighted (e.g., a repository for teaching contents).

Moving to the theme education, digital practices (prácticas digitales) through Internet connect to "virtual" (virtual) via "higher education institutions" (instituciones de educación superior); that shows that different educational experiences with elearning and blended learning in HE are studied. On the other side, there is also a mention to "quality" (calidad), which connects to "teaching" (enseñanza) via higher education. Not only teaching using the resources on the Internet is important, but also that those practices guarantee some degree of quality - a research area that gains special attention in the next time period. 
Finally, in the theme students, evaluation (evaluación) of students' (estudiantes) results (resultados) is one of the main topics of study (estudio) and analysis (análisis). This type of studies include, e.g.: the students' evaluation of educational innovation experiences with different tools (e.g., blogs), the relation between the use of ICT and the students' outcomes or reflections on the general and specific -e.g. concerning functional diversity- possibilities of students with ICT today according to diverse policies.

The quality of learning using technologies (2010-2015): results on students and teachers' perspectives (Fig. 2). In this second period, technologies do not stay at the forefront and "learning" (aprendizaje) is the main theme (675 hits), which is also the central bridge between two of the themes: universities (252 hits) and education (529 hits) as major themes. The last one is "resources" (recursos) (37 hits), which is a new theme with respect to the first period and is connected only to learning.

Within the learning theme, "quality" (calidad) appears again, in this case connected to "courses" (cursos), "online" (en línea), "practices" (prácticas), "environments" (entornos) and "evaluation" (evaluación) via "learning" (aprendizaje). Therefore, in this period, studies are concerned with the quality of learning supported by online courses (cursos),

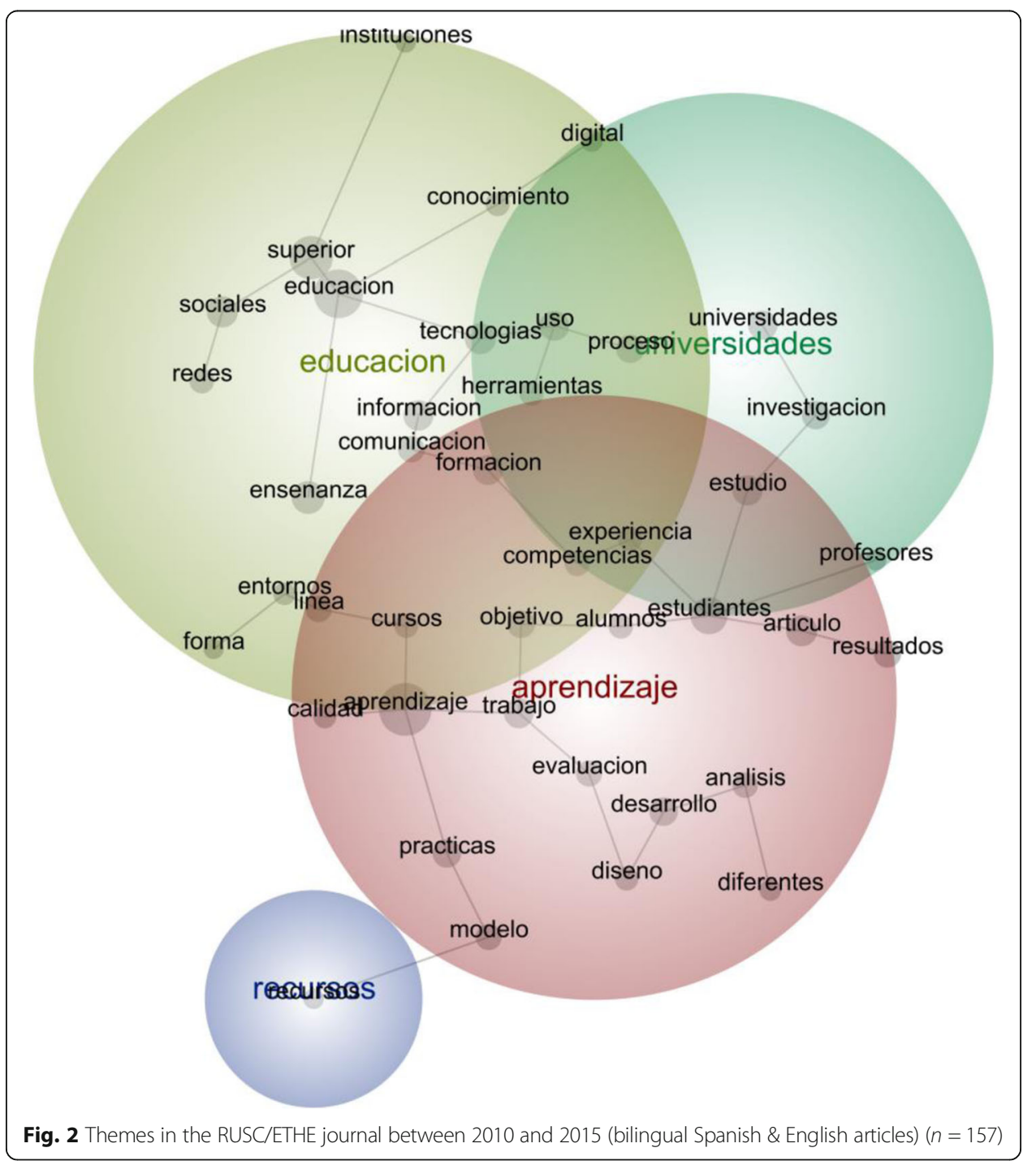


learning environments (entornos en línea), educational "resources" (recursos) and the educational practices (prácticas). The connection of quality with evaluation links also to design and development, showing that the authors investigate the quality and evaluation as part of the design and development processes of educational practices with ICT.

As in the previous period, the use (uso) of technologies (tecnologías) and tools (herramientas) for educational processes (proceso educativo) of teaching (and training (formación), communication (comunicación) and information (información) is highlighted -connections among the learning, education and universities themes. One of the most popular ICT tools for HE institutions (instituciones de educación superior) are social networks (redes sociales).

A new concept appears in connection to the results theme via training: "competencies" (competencias), which connects to students (estudiantes, alumnos) and teachers (profesores). The training of students' and teachers' competencies for the use of information and digital technologies is an important topic in this period, as some articles show.

Focus on the design and development of learning strategies and activities with the use of digital environments and tools (2016-2017) (Fig. 3). In this third and last period of the analysis, learning is still a major theme (233 hits), followed by education (117 hits)

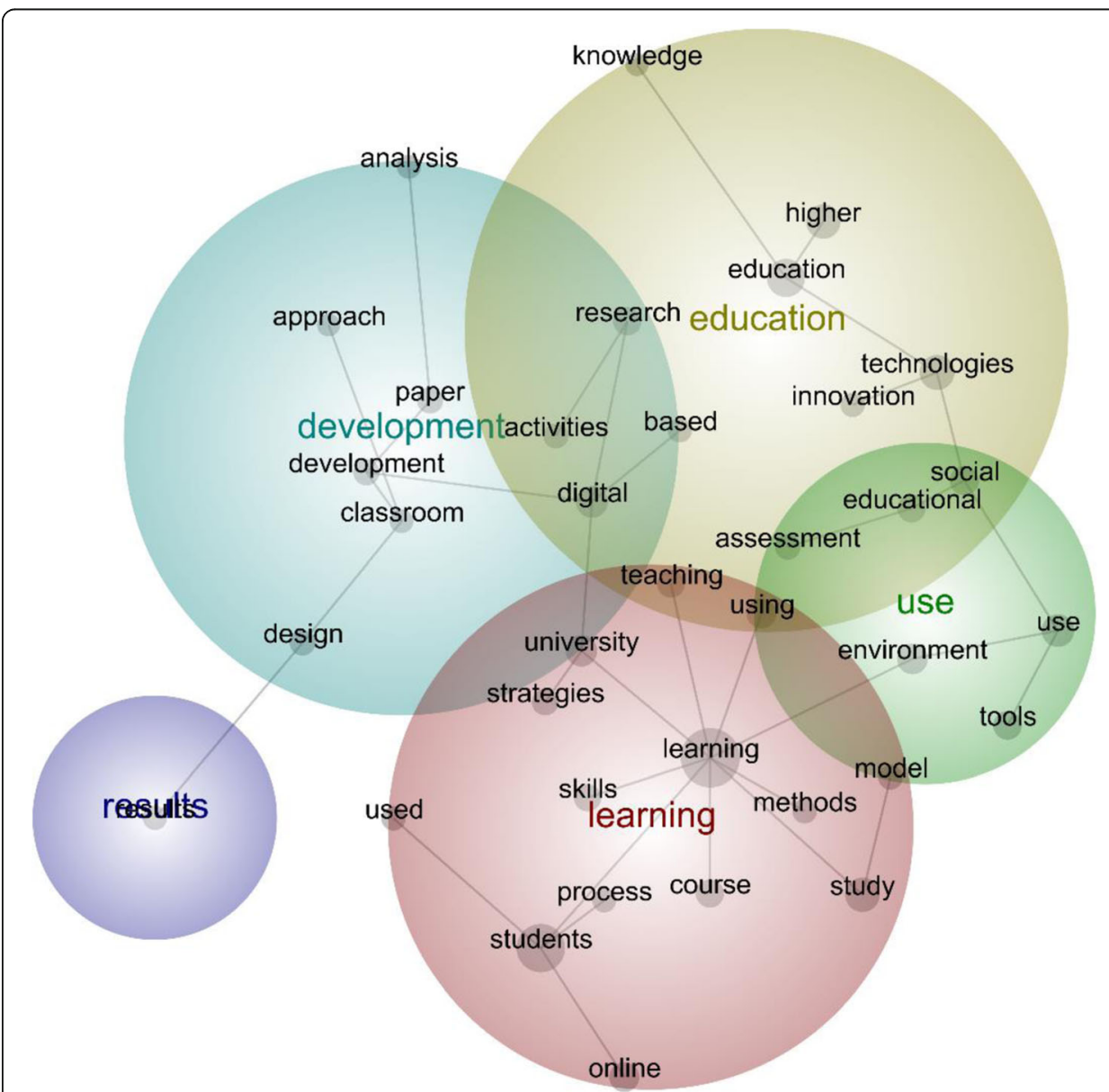

Fig. 3 Themes in the ETHE journal between 2016 and 2017 (only English articles) $(n=64)$. Note: this period contains the half the number of articles of previous periods 
and development (21 hits). The two other main topics are use (126 hits) and results (21 hits). University as one of the main themes has disappeared in this period, even though it is still present in the intersection between learning and development and in the theme education as higher education. Development and use gain importance as themes, compared to other periods.

The main theme is learning and around this topic we can identify different aspects that are relevant in this context, like teaching (overlapping word between learning and education), methods, strategies, course, skills and students. In this period, therefore, learning design and the elements around it are paramount, as can be seen from the literature.

The use of different social technologies, which is connected to innovation in the same education theme, is the bridge between the themes use and education. In this context, studies around the social impact of the use of technologies in the education field and the educational use of social media appear again as relevant topics. Another topic that emerges from the map is the use of virtual learning environments, which connects the themes learning and use.

In the part of the map where the themes education and use overlap, educational assessment is another relevant topic. In this sense, some studies related to the use of eassessment, performance assessment and teachers' and students' assessment of the use of technologies appear.

In this period different educational research studies are developed, in many cases by carrying out learning digital-based activities -e.g. in blended learning environments or collaborative projects-, but not exclusively. The four concepts research, activities, digital, and based are located in the overlapping area between development and education. The minor theme in relevance here (results) remains connected to the theme development via classroom design, since its main approach is concerned with the evaluation of the outcomes from the designed educational scenarios.

\section{Additional file}

Additional file 1: Data examples (references) related to the description of the maps. (DOC $36 \mathrm{~kb}$ )

Authors' contributions

All authors read and approved the final manuscript.

Competing interests

The authors declare that they have no competing interests.

\section{Publisher's Note}

Springer Nature remains neutral with regard to jurisdictional claims in published maps and institutional affiliations.

Author details

${ }^{1}$ Carl von Ossietzky Universität Oldenburg, Oldenburg, Germany. ${ }^{2}$ Universitat Oberta de Catalunya, Barcelona, Spain.

${ }^{3}$ Universidad de los Andes, Bogotá, Colombia.

Received: 4 January 2018 Accepted: 10 January 2018

Published online: 18 January 2018

References

Hsu, Y. C., Hung, J. L., \& Ching, Y. H. (2013). Trends of educational technology research: More than a decade of

international research in six SSCl-indexed refereed journals. Educational Technology Research and Development, 61(4), 685-705. https://doi.org/10.1007/s11423-013-9290-9.

Krippendorff, K. (2013). Content analysis: An introduction to its methodology (3rd ed.). Los Angeles, CA: Sage. 
Leximancer. (2016). Leximancer manual version 4.5. Retrieved from http://info.leximancer.com/.

Marín, V. I., Zawacki-Richter, O., Pérez Garcias, A., \& Salinas, J. (2017). Educational Technology Trends in the Ibero-american World: 20 Years of the Edutec-E Journal. Edutec-E. Revista Electrónica de Tecnología Educativa, (59). doi:https:/doi.org/10.21556/edutec.2017.59.836.

Ramiro, M. T., Ramiro-Sánchez, T., \& Alba-Ruiz, R. (2014). Bibliometric profile of RUSC. Universities and knowledge society journal. RUSC. Universities and Knowledge Society Journal, 11(3), 42-62. https://doi.org/10.7238/rusc.v11i3.2167.

Schreier, M. (2014). Qualitative Content Analysis. In U. Flick (Ed.), The SAGE Handbook of Qualitative Data Analysis. London, UK: Sage. doi:https://doi.org/10.4135/9781446282243.n12.

Zawacki-Richter, O., Alturki, U., \& Aldraiweesh, A. (2017). Review and Content Analysis of the International Review of Research in Open and Distance/Distributed Learning (2000-2015). The International Review Of Research In Open And Distributed Learning, 18(2). doi:https://doi.org/10.19173/irrodl.v18i2.2806.

Zawacki-Richter, O., \& Naidu, S. (2016). Mapping research trends from 35 years of publications in Distance Education. Distance Education, 37(3), 245-269. doi: https://doi.org/10.1080/01587919.2016.1185079.

Submit your manuscript to a SpringerOpen ${ }^{\circ}$ journal and benefit from:

- Convenient online submission

- Rigorous peer review

- Open access: articles freely available online

High visibility within the field

- Retaining the copyright to your article

Submit your next manuscript at $\gg$ springeropen.com 